\title{
CRETACEOUS INSECTS FROM LABRADOR. 4. A NEW FAMILY OF BEETLES (COLEOPTERA: ARCHOSTEMATA)*
}

\author{
By A. G. Ponomarenko \\ Paleontological Institute \\ Academy of Sciences of the USSR
}

Through the kindness of Professor F. M. Carpenter, I have been able to study some fossil beetles from Cretaceous strata in Northern Labrador, Canada, collected by Professor Erling Dorf of Princeton University and contained in the paleontological collections of that university. The age of the deposit in which the beetles were found is early Cenomanian or very late Albian, as shown by the pollen and plant fragments (Dorf, I967). The collection of beetles consists of eight elytra.

Four of these elytra (nos. 87272, 87274, 87275, 87276) have preserved the structure described by Rohdendorf (196I) as a furrow ("schiza"). Study of Recent beetles has shown this structure to be a process on the underside of the elytron, present only in water beetles. Functionally, it is a part of the device for keeping air in the subelytral space. Since elytra such as these are very common among schizophoroid beetles, which are numerous in Mesozoic deposits of mid-Asia (Ponomarenko, 1968, 1969), their generic affinities cannot be determined without knowledge of additional morphological details.

Two other elytra (nos. 8727I and 87278) have longitudinal striae. This sculpturing of elytra is very common and the systematic position of beetles cannot be determined satisfactorily by it. One of these elytra, however, on the basis of the shape of the elytron with an oblique base, ten rows of large punctures and a complete slender line along the sutral margin, bears a strong resemblance to the haliplid Peltodytes.

The two remaining elytra belong to the Archostemata. One specimen (no. 87277) belongs to the family Cupedidae. Although most Recent cupedid genera are present in the New World, this is the

\footnotetext{
*Research aided by NSF Grant no. GB7308, F. M. Carpenter, principal investigator.

The previous parts in this series were published in Psyche, vol. 74, pp. 267289, 1967.
} 


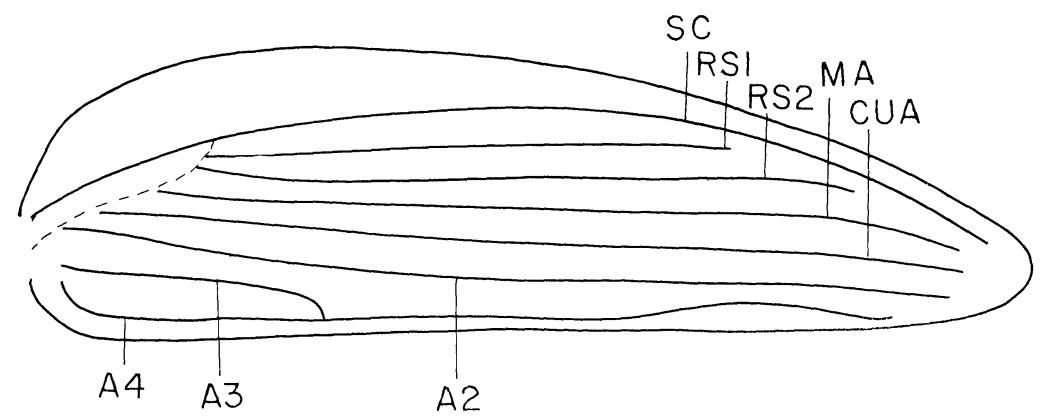

Figure 1. Elytron of Labradorocoleus carpenteri, gen. nov., sp. nov. Interpretation of venation based on Tshekardocoleidae.

first fossil cupedid from that region. In structure, the elytron is similar to that of Omma and Tetraphalerus (these two genera being indistinguishable on elytral structure). Modern Omma occurs in Australia, and Tetraphalerus in South America, but numerous fossils of these beetles have been found in Mesozoic deposits of Europe and Asia (Ponomarenko, I968). The other specimen (no. 87273) from Labrador is unquestionably representative of a new family. This elytron shows a number of primitive features and is related to the Lower Permian family Tshekardocoleidae (Rohdendorf, I944; Ponomarenko, 1963, 1969; Kukalová, 1965, 1969) from Russia and Czechoslovakia. Among the thousands of Permian and Mesozoic beetles studied by the author, there are no other members of this new family or forms intermediate between it and the tshekardocoleids.

Family Labrodorocoleidae, fam. nov.

This family is based on a single genus, Labradorocoleus, gen. nov., known only from an elytron. Elytron very convex basally, flattened to the apex, which is rounded. Epipleural (costal) space very wide in the proximal half, with several rows of large rounded cells. Venation of elytron cellulate, the principal and intermediate longitudinal veins being clearly distinguishable. Seven principal longitudinal veins present and parallel to the sutural margin. The nomenclature of these veins, based on a comparison with elytral venation of the tshekardocoleids, is shown in figure $\mathrm{I} . \mathrm{A}_{3}$ is very long; two rows of cells present between $\mathrm{A}_{3}$ and $\mathrm{A}_{4}$, one row of distinct cells between $A_{4}$ and the sutural margin.

This new family is related to the Tshekardocoleidae by having a wide epipleural margin with several rows of cells, two Rs veins, a long $\mathrm{A}_{3}$, two rows of cells between $\mathrm{A}_{3}$ and $\mathrm{A}_{4}$, and one row 


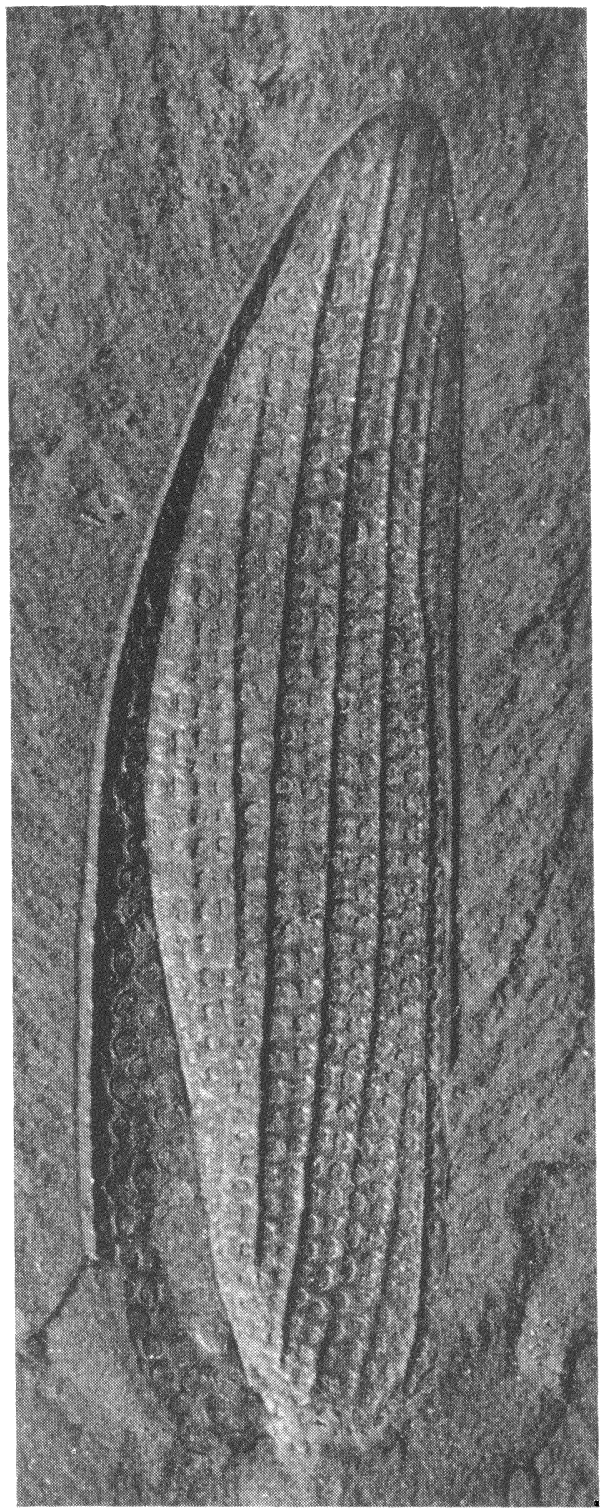

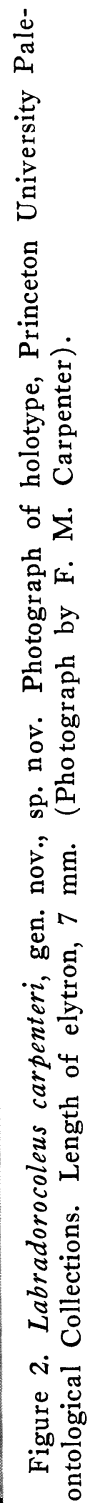


between $\mathrm{A}_{4}$ and the sutural margin. It is distinguished by the complete reduction of $\mathrm{CuP}$ and by having all veins parallel to the elytral margin.

Labradorocoleus, gen. nov.

Type species: Labradorocoleus carpenteri, sp. nov.

Epipleural space narrowing to apex. The rs2-area is narrow before the middle of the elytron, with one row of cells; two rows present in the distal part of the elytron. The rest of the areas with two rows of cells. A3 more than a quarter the length of the elytron, the second row of cells in its area very short. Cells in the 24-area typically large.

This genus includes a single species from Cretaceous deposits of Canada.

\section{Labradorocoleus carpenteri, sp. nov.}

Figures $I$ and 2

Epipleural space on the base with four rows of cells, with three rows in the basal third, one row in the apical third. Apical third with $\mathrm{A}_{4}$ curved forward. Cells of elytron broader than the veins. Intermediate longitudinal veins for the most part straight.

Length of elytron: $7 \mathrm{~mm}$.

Holotype: No. 87273 a,b, Invertebrate Paleontology collections, Princeton University. It is a well-preserved, isolated, right elytron. The humeral part, however, is damaged, and the bases of all the veins, except the anal, are impossible to distinguish. The fossil was collected by Professor Erling Dorf in 1958, at Redmond No. I deposit in the Knob Lake District (near Schefferville), Labrador, Canada.

The species is named in honor of Professor F. M. Carpenter, whose courtesy and aid made possible this study.

The discovery of this beetle, with its many tshekardocoleid-like features, is very interesting. Such features were lost by all other beetles during Upper Permian time. The labradorocoleids appear to have developed the complete elytral venation independently of the tshekardocoleids and at a later time; yet this family is not interediate between the tshekardocoleids and more advanced forms like cupedids and permocupedids, for the rudimentary $\mathrm{CuP}$, which is present in permocupedids, is absent in the labradorocoleids. Thus, the mechanical perfection of elytral venation was evolved in parallel with that of the permocupedid-cupedid line. In conclusion, then, the labradorocoleids arose from a tshekardocoleoid branch of archo- 
stemate beetles evolving with the permocupedid-cupedid branch, and formed with this line, a "sibling-group" in the sense of Hennig.

DORF, E.

\section{REFERENCES}

1967. Cretaceous Insects from Labrador. 1. Geologic Occurrence. Psyche, 74(4) : 267-269.

Kukalová, J.

1965. Permian Protelytroptera, Coleoptera and Protorthoptera (Insecta) of Moravia. Sbornik Geologickych ved. paleont. rada P, 6: 91-98.

Ponomarenko, A. G.

1963. Paleozoic Beetles Cupedidea of Europe (USSR). Paleontological Journal, 1: 70-85. (In Russian).

1968. Archostematid Beetles from Jura of Karatau. In Jurassic Insects of Karatau. Acad. Sci. USSR, Moscow. pp. 18-138. (In Russian).

1969. The Evolution of Archostematid Beetles. "Nauka," Moscow. In press. (In Russian).

ROHDENDORF, B. B.

1944. A New Family of Beetles From Permian Deposits of Ural. DAN, USSR, 44(6): 277-279. (In Russian). 

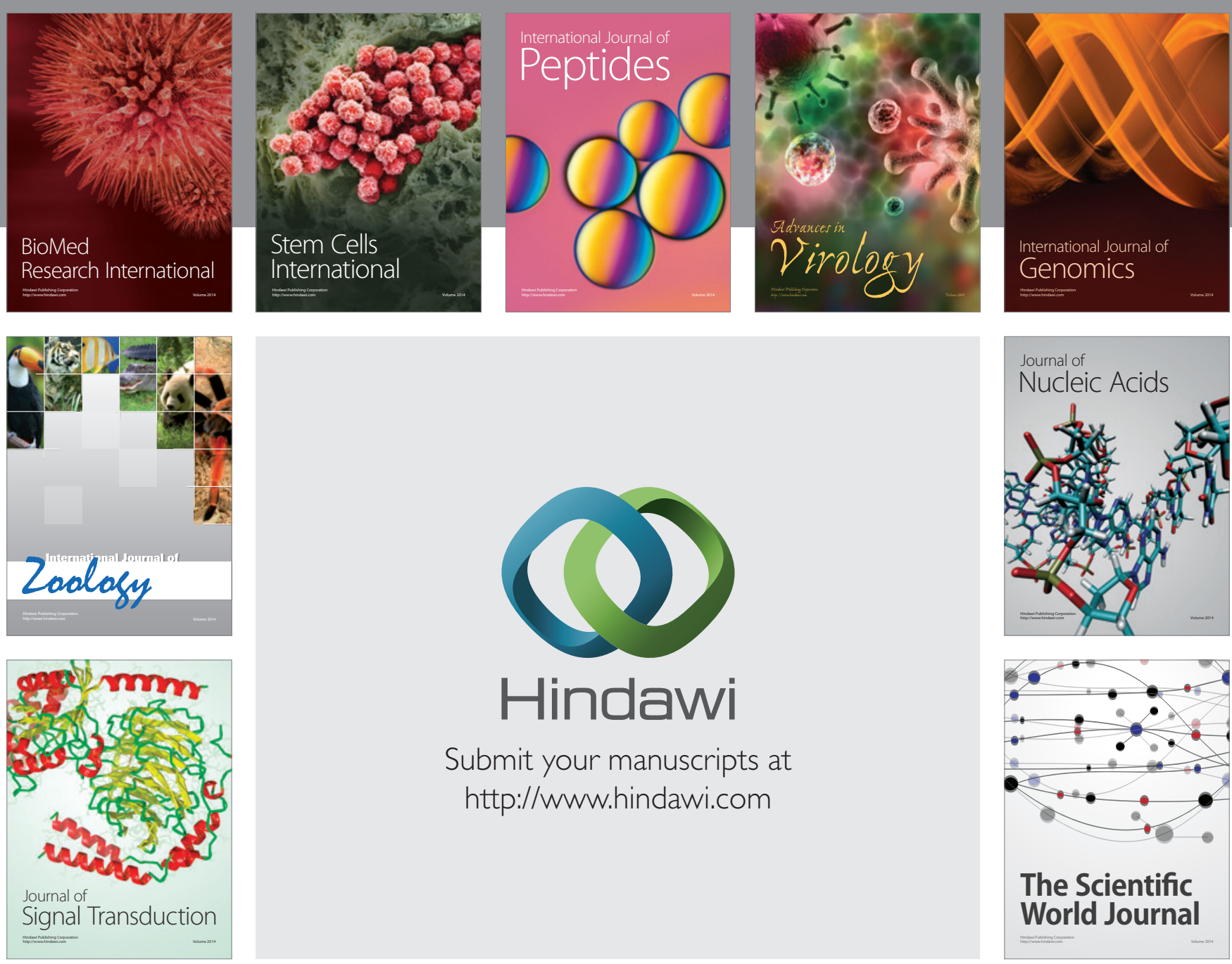

Submit your manuscripts at

http://www.hindawi.com
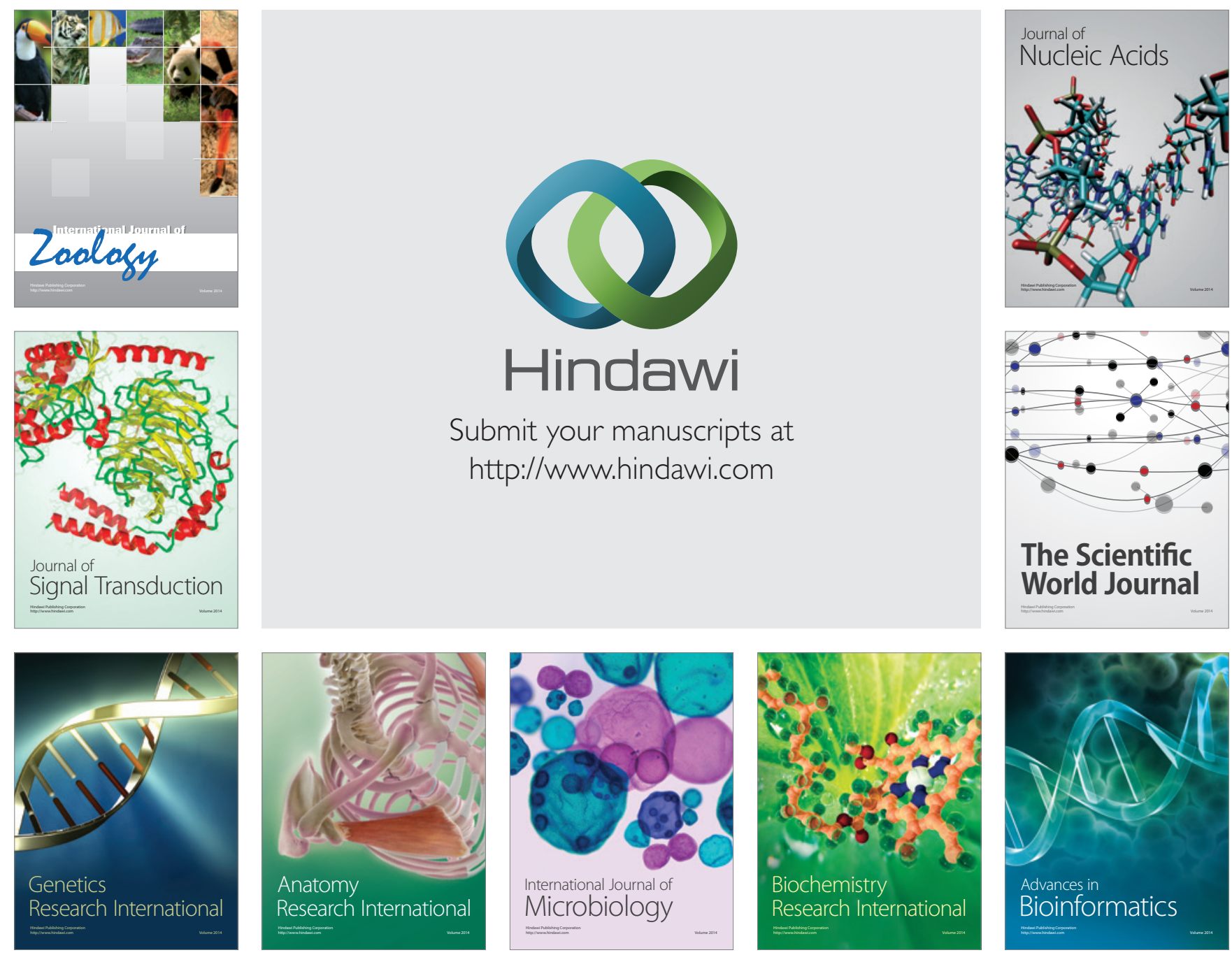

The Scientific World Journal
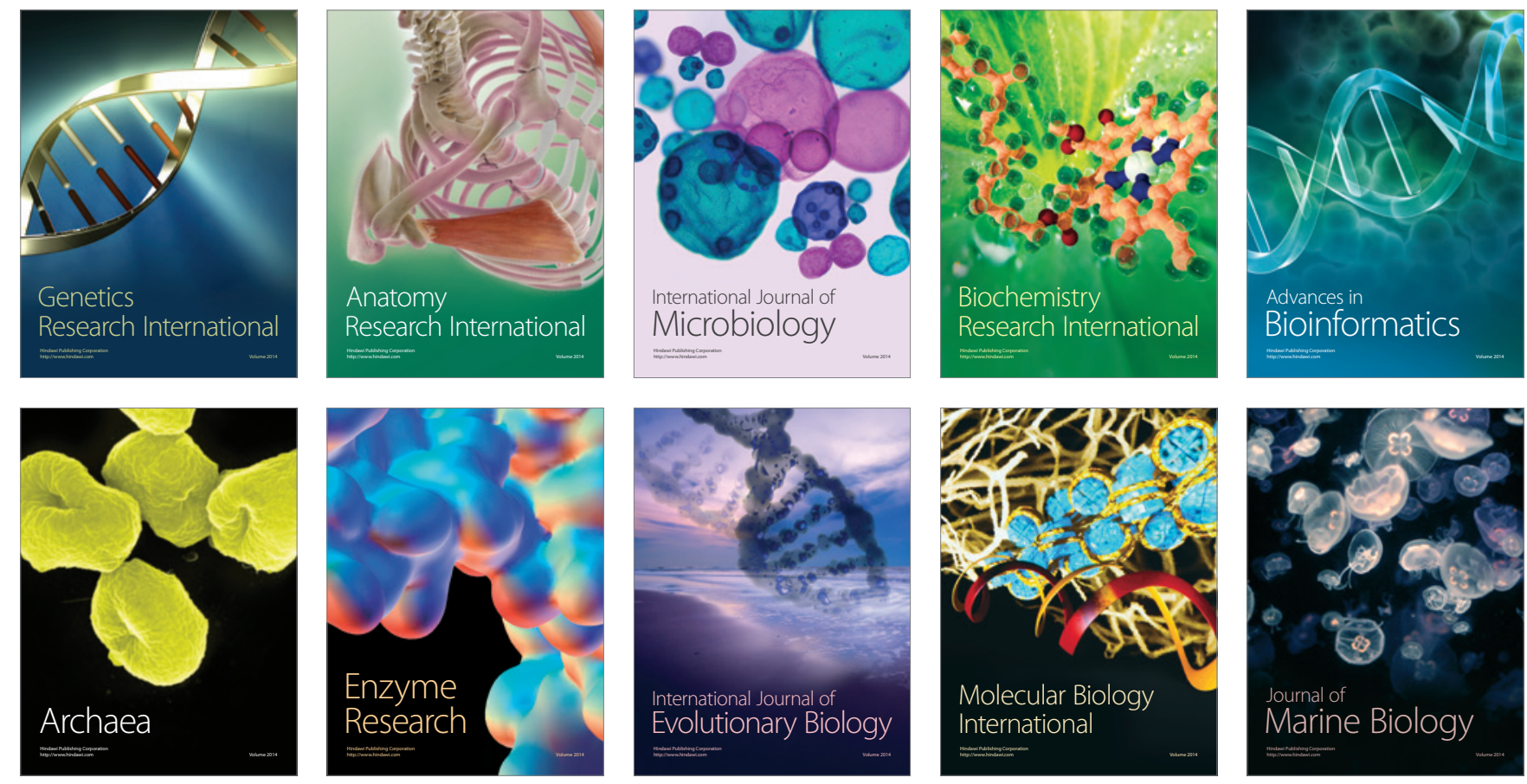